\title{
Robert Tyrata
}

Uniwersytet Papieski Jana Pawta II w Krakowie

Akademia Muzyczna, Kraków

\section{Regulamin organistów w archidiecezji krakowskiej ${ }^{1}$}

Regulacja życia kościelnego organistów diecezji krakowskiej ma swoją długą i ciekawą historię. Nie brakowało w niej mądrych biskupów, a także odważnych ludzi świeckich i duchownych podejmujących ten problem.

\section{Historia prawnych regulacji posady organistów w diecezji krakowskiej}

Sprawy dotyczące uposażenia organistów, a także konieczności podpisywania umów o pracę z parafiami, poruszane były w kolejnych numerach urzędowego pisma Kościoła w Krakowie pt. „Notificationes” od początku XX wieku. Na zjeździe księży dziekanów w 1907 roku uchwalono uregulowanie stosunku między rządcami kościołów a organistami. Uchwała weszła w życie w 1908 roku. Polecano w niej zawarcie umowy z organistą i zamieszczono w dokumencie jej wzór ${ }^{2}$. Konsystorz polecał zawieranie umowy o pracę z każdym organistą. Jeśli zaś w jakiejś parafii organista nie miał mieszkania, proboszcz winien był mu je zorganizować. Jeżeli w jakiejś parafii istniał grunt dla utrzymania organisty, rządcy kościołów mieli oddać go organiście. Proboszczowie też mieli pomóc organiście w znalezieniu dodatkowej pracy w celu utrzymania swojej rodziny. Decyzja zapadła 15 lipca 1908 roku. Podpisani pod odezwą do organistów Walenty Dec oraz Tomasz Flasza pisali wówczas:

Podając do wiadomości pp. Organistów niniejsze rozporządzenie, Towarzystwo wzaj. Pomocy oznajmia, że rozporządzeniem tem Książ. Biskup-Konsystorz

1 Wykład wygłoszony w Pelplinie podczas Kongresu Muzyków Kościelnych w dniu 19 maja 2012 roku.

2 W sprawie organistów, zarys kontraktu, „Notificationes”, VII (1908), s. 81-83; R. Tyrała, Cecyliański ruch odnowy muzyki kościelnej na ziemiach polskich do 1939 roku, Kraków 2010, s. 123. 
ma na celu polepszenie bytu materialnego i zabezpieczenie na posadach organistów. Niechże więc organiści godnie odpowiedzą spełnieniem swoich obowiązków z jednej strony, zaś z drugiej niech dopilnują, ażeby zamiast poprawy, nie pogorszyli sobie bytu³.

W 1909 roku zamieszczono także przypomnienie o ustawowym ubezpieczeniu organistów na starość ${ }^{4}$. Do tego dokumentu odwoływało się także zarządzenie z 1914 roku, które polecało taką umowę koniecznie zawierać.

Polecamy tedy wszystkim Rządcom kościołów dyecezyi Naszej, którzy na piśmie umowy z organistą nie zawarli, ażeby co rychlej do rozporządzenia z r. 1908 się zastosowali, a na przyszłość nakazujemy, by ilekroć nowego przyjmą organistę, zawsze z nim umowę pisemną zawieralí5.

Wraz z próbą regulacji spraw organistowskich, ich bytu i zapłaty za pracę żywo obecna była sprawa podnoszenia ich poziomu muzyczno-intelektualnego. $28 \mathrm{lu}$ tego 1910 roku weszło też w życie rozporządzenie podane do wiadomości na temat zakresu znajomości przedmiotów zdawanych na egzaminie organistowskim, składanym przed komisją diecezjalną w Krakowie. Obejmował on wiadomości z zakresu teorii muzyki (elementarne wiadomości z zakresu harmonii, należało zharmonizować pieśń kościelną w 4-głosowym układzie skupionym ze znajomością modulacji), gry na organach (kandydat miał zagrać przygrywkę przygotowaną przez siebie, zagrać kilka przygrywek przedstawionych przez komisję, odpowiedzieć na intonację kapłana, wykonać dialogi mszalne, improwizację, zagrać pieśń kościelną wedle podanej intonacji), ze śpiewu gregoriańskiego (czytać miał nuty na czterolinii, trafiać interwały i melodię chorałową wedle kancjonału, wykazać się dokładną znajomością tonów kościelnych i umiejętnością towarzyszenia na organach do śpiewu gregoriańskiego), z liturgiki (wykazać się znajomością roku kościelnego, szat, naczyń, ksiąg liturgicznych, znajomością rubryceli, znajomością na pamięć ministrantury). Kandydaci starający się o miejsce w miejskich parafiach mieli wykazać się umiejętnościami organizatorskimi oraz sztuką prowadzenia chóru. Kandydat miał przedstawić życiorys, świadectwo nauki szkolnej (ostatnie), świadectwo moralności z urzędu parafialnego. Egzamin miał odbywać się dwa razy w roku: w maju oraz w listopadzie. Podania trzeba było posłać do

3 Zob. Do p. organistów diecezji krakowskiej, ŚK XIII (1908), nr 24, s. 432-436.

4 Okólnik do Wielebnych xx. Proboszczów w sprawie ustawowego ubezpieczenia organistów na starość, „Notificationes”, X-XII (1909), s. 96.

5 W sprawie umowy z organistami, „Notificationes”, X-XI (1914), s. 56. 
konsystorza lub wprost do przewodniczącego komisji egzaminacyjnej, którym był ks. dr Czesław Wądolny. Dokument ten podpisał kard. Jan Puzyna ${ }^{6}$.

Sprawa uposażenia oraz obowiązków organistów zostaje ostatecznie uporządkowana na podstawie Regulaminu stużbowego dla organistów w dyecezyi krakowskiej w $1919 \mathrm{roku}^{7}$. Ten rok jest także początkiem regulacji dotyczącej ustanowienia komisji diecezjalnej dla organistów. Przewodniczącym został wówczas ks. Czesław Wądolny ${ }^{8}$, a członkami: ks. Jan Krupiński, ks. Michał Kołodziej, ks. Józef Caputa oraz organiści i świeccy współpracownicy w dziedzinie muzyki kościelnej, a mianowicie: Stanisław Niepielski, Tomasz Flasza, Kazimierz Garbusiński i Walenty Dec $^{9}$. Na kanwie zalecanej przez Stolicę Apostolską odnowy muzyki kościelnej już pod koniec XIX wieku ${ }^{10}$ ukazuje się zachęta do ujednolicenia spraw muzyki kościelnej w diecezji krakowskiej. Poleca się bowiem, by wprowadzić konieczne dla organisty muzykalia. Właśnie w tym celu Towarzystwo Wzajemnej Pomocy Organistów Dyecezyi Krakowskiej wydaje Śpiewnik kościelny katolicki ${ }^{11}$.

Regulamin dla organistów przygotowywany był przez zgromadzenie delegatów organistów, które miało miejsce w Krakowie w dniu 8 stycznia 1919 roku i na które przybyło 72 wysłanników. Był to zjazd delegatów polskich, chociaż

[...] z zaboru pruskiego delegaci nie przybyli z powodu trudności na granicy niemieckiej [...] z byłego zaboru rosyjskiego przybyli delegaci z Kielc, Olkusza, Dąbrowy, Sosnowca [...] był obecny ks. L. Kasprzyk, kierownik sekretariatu katol. Stowarzyszeń robotniczych. Z strony Konsystorza, mimo zaproszenia nikt nie przyby ${ }^{12}$.

Wiele tematów dotyczących organistów było przedstawianych na tym spotkaniu. Zakończyło się ono rezolucją, w której pokreślono, że:

6 Zob. Akta luźne, organiści 1916-21, AKMK.

7 Uregulowanie spraw organistów $w$ dyecezyi krakowskiej, „Notificationes”, I-II (1919), s. 10; Regulamin stużbowy dla organistów w dyecezyi krakowskiej, tamże, s. 11-16; R. Tyrała, Cecyliański ruch odnowy muzyki kościelnej na ziemiach polskich do 1939 roku, dz. cyt., s. 192.

8 Zob. S. Piech, Wychować dla Kościota i Państwa. Formacja elity duchowieństwa galicyjskiego $w$ Wiedniu 1775-1918, Kraków 2009, s. 333.

9 Sktad cztonków dyecezalnej Komisji dla spraw organistowskich w myśl p. 3 powyższego regulaminu, „Notificationes”, III-VIII (1919), s. 16.

${ }^{10}$ Zarządzenia Stolicy Apostolskiej z dn. 24 września 1884 i 6 lipca 1894 roku.

${ }^{11}$ W sprawie muzyki kościelnej i śpiewu, poleca się śpiewnik kościelny katolicki, „Notificationes”, X-XI (1903), s. 81-82.

${ }^{12}$ Protokót ze zgromadzenia delegatów organistów polskich odbytego w dniu 8 stycznia 1919 w Krakowie, Akta luźne, organiści 1916-1922, AKMK. 
[...] zjazd upoważnia komitet, aby po raz ostatni zwrócił się do Konsystorza w sprawie uregulowania stosunków organistowskich ${ }^{13}$.

Skuteczne okazały się rezolucje zjazdu, bowiem w tym samym roku regulamin został podpisany.

Ten na ówczesne czasy nowatorski regulamin dla organistów określał podział posad organistowskich na kategorie ${ }^{14}$, warunki objęcia posady ${ }^{15}$, obowiązki komisji do spraw organistowskich w sytuacjach załatwiania spraw bieżących, ale także i spornych ${ }^{16}$; opisywał, jak ma nastąpić objęcie stanowiska organisty, jaką rolę pełni rządca kościoła jako bezpośredni przełożony oraz jakie są obowiązki i prawa organisty ${ }^{17}$. Kolejno podejmował tematy: pod jakimi warunkami organista może wziąć zastępstwo, co grozi mu za samowolne oddalenie się od pracy, jakie przysługują mu urlopy oraz przejście w stan emerytalny. Określał także obowiązki w pracy, jak również kary za ich niewypełnianie ${ }^{18}$. Regulamin miał moc obowiązującą od dnia 1 lipca 1919 roku. Na końcu zamieszczono cennik płacy dla organistów zawierający stałe roczne pobory, osobne wynagrodzenia oraz części dochodów z tzw. iura stolae. We wstępie zaś zapisano:

[...] sprawa organistów od dawna domagała się uregulowania, [...] spodziewamy się, że załatwiając w ten sposób tę leżącą Nam na sercu sprawę, spotkamy po stronie organistów całą ich dobrą wolę i że będzie podstawą do szczerego ich do Kościoła św. przywiązania i bodźcem do przestrzegania we wszystkim chwały Bożej, która ich zawodu ostatecznym jest celem ${ }^{19}$.

Pewne późniejsze dookreślenia dodano w statutach Synodu Diecezjalnego z 1923 roku, ale regulamin pozostał w takim samym kształcie jak wcześniej ${ }^{20}$.

W 1934 roku ukazał się w archidiecezji krakowskiej kolejny Regulamin stużbowy dla organistów $w^{21}$, który w dniu 24 lutego podpisał książę Adam Stefan Sapieha.

13 Tamże; R. Tyrała, Cecyliański ruch odnowy muzyki kościelnej na ziemiach polskich do 1939 roku, dz. cyt., s. 192.

${ }_{14}$ Zob. Regulamin dla organistów dyecezyi krakowskiej, Kraków 1919, wstęp.

15 Zob. tamże, art. 2.

16 Zob. tamże, art. 3.

17 Zob. tamże, art. 4-11.

${ }_{18}$ Zob. tamże, art. 12-18.

19 Tamże, wstęp.

${ }^{20}$ Zob. Synodus Dioecesana Cracoviensis Anno Domini MCMXXIII Celebranta, Kraków 1923.

${ }^{21}$ Zob. Regulamin stużbowy dla organistów Archidiecezji krakowskiej, Kraków 1934, AKMKK, bez sygn.; R. Tyrała, Cecyliański ruch odnowy muzyki kościelnej na ziemiach polskich do 1939 roku, dz. cyt., s. 196. 
We wstępie do wydanego drukiem regulaminu biskup zwracał uwagę, że regulamin dotąd obowiązujący z 19 czerwca 1919 roku został uzupełniony przez uchwały Synodu Diecezjalnego z roku 1923.

Zmienione warunki ekonomiczne, społeczne, ustawowe i kulturalne, jak niemniej wielkie wymagania, jakie nakłada obecna doba, domagały się koniecznie zmiany dotychczas obowiązującego regulaminu dla organistów ${ }^{22}$.

Regulamin przedstawiał podział posad organistowskich na kategorie I i II, warunki objęcia posady organisty, obowiązki i zadania, jakie stają przed Arcybiskupią Komisją dla Spraw Organistowskich. Opisywał też, jak powinno nastąpić objęcie posady organisty, jakie są władze organistowskie. Dalej: jakie są jego obowiązki, jak ma wyglądać jego wynagrodzenie, mieszkanie oraz zmiana posady. $\mathrm{Na}$ końcu umieszczono także wzór umowy służbowej oraz podano, że regulamin ma moc obowiązującą od dnia 1 kwietnia 1934 roku w całej archidiecezji ${ }^{23}$.

W czasie po Soborze Watykańskim II pojawiały się w Kościele w Polsce - jako efekt pracy synodów diecezjalnych - statuty bądź regulaminy dla organistów. Nie inaczej było też w archidiecezji krakowskiej. Synod archidiecezji krakowskiej w latach 1972-1979, rozpoczęty przez kard. Karola Wojtyłę, zakończony przez abpa Franciszka Macharskiego w obecności papieża Jana Pawła $\mathrm{II}^{24}$, podjął także temat muzyki kościelnej. Jako efekt pracy synodu duszpasterskiego powstał Regulamin organistów archidiecezji krakowskiej25. Przygotowany został przez Podkomisję ds. Organistowskich, a kardynał Karol Wojtyła dekretem z dnia 1 lutego 1978 roku zatwierdził go na okres pięciu lat. Regulamin ten podejmował temat władz organistowskich, problem zawarcia umowy o pracę, określał obowiązki organisty, jego uposażenie, ubezpieczenie i emeryturę oraz zapewniał prawo do urlopu. Określał także warunki rozwiązania stosunku służbowego. Na końcu zostały także podane dwa wzory umowy o pracę.

Rok 2000 w archidiecezji krakowskiej przynosi kolejny regulamin. 28 października 2000 roku kard. Franciszek Macharski podpisuje nowy regulamin,

22 A. S. Sapieha, W sprawie Regulaminu stużbowego dla organistów Archidiecezji Krakowskiej, L 1843/34, AKMKK, bez. sygn.

${ }^{23}$ Zob. Regulamin stużbowy dla organistów Archidiecezji krakowskiej, Kraków 1934, AKMKK, bez. sygn.

${ }^{24}$ Zob. Duszpasterski synod archidiecezji krakowskiej 1972-1979. Przebieg prac synodalnych. Dokumenty synodu. Dokumentacja synodu, t. 1 i 2, Kraków 1985.

${ }_{25}$ Zob. Regulamin organistów archidiecezji krakowskiej, „Notificationes”, VII-VIII (1978), s. 208-222. 
który zostaje wprowadzony na okres pięciu lat ${ }^{26}$. Bp Kazimierz Nycz - ówczesny wikariusz generalny metropolity krakowskiego - we wprowadzeniu do drukowanej wersji regulaminu pisał:

Regulamin $[\ldots]$ jest nowym narzędziem w ręku księży, organistów i organistek. Jeśli pomoże w rozwiązaniu spraw zatrudnienia, wynagrodzenia, a nade wszystko w pełnieniu pięknej misji służenia liturgii, to spełni swą rolę ${ }^{27}$.

Regulamin został podzielony na działy, które poruszały następujące kwestie: władze organistowskie, cele i zadania podkomisji ds. organistowskich, charakter prawny stanowiska organisty, podział stanowisk i wymagane kwalifikacje, objęcie stanowiska, umowa o pracę, obowiązki organisty, uposażenie organisty, ubezpieczenie i emerytura, prawo do urlopu, rozwiązanie stosunku służbowego, przepisy końcowe. Zawarty został także wzór umowy o pracę.

22 listopada 2005 roku, we wspomnienie św. Cecylii - patronki muzyki kościelnej - arcybiskup Stanisław Dziwisz, metropolita krakowski, podpisał nowy regulamin dla organistów ${ }^{28}$. Był on nieco zmodyfikowaną, ulepszoną formą poprzedniego regulaminu i kolejną próbą systematyzowania spraw organistowskich w archidiecezji krakowskiej.

Dopowiedzieć tutaj także trzeba, że równocześnie $\mathrm{z}$ tworzeniem regulacji prawnych w archidiecezji krakowskiej porządkowano sprawę wykształcenia (coraz bardziej w regulaminie na to zwracano uwagę). I tak w 1998 roku powstała Archidiecezjalna Szkoła Organistowska (dzisiaj Archidiecezjalna Szkoła Muzyczna II stopnia), która zastąpiła dawniej istniejące studium dla organistów. Zaś w 2008 roku powołano do istnienia Międzyuczelniany Instytut Muzyki Kościelnej, który poprzez współpracę Akademii Muzycznej w Krakowie i Uniwersytetu Papieskiego Jana Pawła II w Krakowie kształci na kierunku muzyka kościelna na studiach I i II st. (licencjat zawodowy, magisterium) studentów, którzy zajmować będą poszczególne parafie w przynależnych ich kategoriach.

W 2011 roku ukazał się najnowszy Regulamin organistów archidiecezji krakow$s k i e j^{29}$, który jest efektem pracy organistów i duchownych, prawników cywilnych i kościelnych.

${ }^{26}$ Zob. Regulamin organistów archidiecezji krakowskiej, Kraków 2000.

${ }^{27}$ K. Nycz, Wprowadzenie. Regulamin organistów archidiecezji krakowskiej, Kraków 2000, s. 2.

${ }^{28}$ Zob. Regulamin organistów archidiecezji krakowskiej, Kraków 2005.

${ }^{29}$ Zob. Regulamin organistów archidiecezji krakowskiej, Kraków 2011. 


\section{Regulamin organistów archidiecezji krakowskiej z 2011 roku}

Nim doszło do podpisania Regulaminu organistów archidiecezji krakowskiej, blisko trzy lata członkowie Archidiecezjalnej Komisji Muzyki Kościelnej, wybrani proboszczowie archidiecezji, prawnicy kościelni i cywilni przygotowywali ów dokument. Był on przedstawiany wielokrotnie na spotkaniach organistów i księży, słuchano także ich uwag i je realizowano.

23 czerwca 2011 roku, w uroczystość Bożego Ciała, kardynał Stanisław Dziwisz, metropolita krakowski, podpisał nowy, obowiązujący od tego momentu Regulamin organistów archidiecezji krakowskiej ${ }^{30}$. Sam też we wstępie do tego dokumentu napisał:

Dziękuję, że zapowiadany przeze mnie w liście do organistów w listopadzie 2010 roku dokument, został ukończony i dzisiaj ukazuje się z mocą obowiązującą dla tej cząstki Kościoła jaką jest Archidiecezja krakowska. Proszę byście wszyscy konsekwentnie zrealizowali jego zawartość. Niezmiernie istotne jest jasne ukształtowanie dobrej współpracy pomiędzy księżmi a organistami. Bardzo ważne, by ta relacja była oparta na sprawiedliwości społecznej i na przejrzystości, także finansowej. Tylko w ten właśnie sposób będziemy wierni ideałom Założyciela Kościoła. Temu służy ten właśnie dokument ${ }^{31}$.

Zwrócił także uwagę na poszanowanie organistów oraz na to, że to właśnie oni odpowiadają za muzykę kościelną w kościołach archidiecezji.

Ta regulacja prawna jest bardzo ważna dla nas wszystkich. Niezmiernie istotne jest poszanowanie pracy organisty w naszych świątyniach, ale także świadomość duchownych, że organiści są ich najbliższymi współpracownikami w dziedzinie muzyki kościelnej. Co więcej, to oni właśnie za kształt tej muzyki odpowiadają i im powinniśmy powierzyć tę część naszej odpowiedzialności za Kościół. Sami zaś organiści winni odznaczać się szacunkiem do każdego duchownego. Nasi organiści są doskonale przygotowani muzycznie do spełniania swojego powołania przez: Archidiecezjalną Szkołę Muzyczną II st. i Międzyuczelniany Instytut Muzyki Kościelnej, działające w Krakowie. Dlatego też możemy być pewni, że są dobrze ukształtowani do tej służby w Kościele krakowskim. Ci zaś, który pracują już

\footnotetext{
30 Tamże.

31 Tamże, s. 3.
} 
w naszych świątyniach, muszą też ciągle się rozwijać, aby powołanie, które pełnią w Kościele, było autentyczne ${ }^{32}$.

Ten dokument prawny zawiera rozdziały poruszające następujące kwestie: przepisy wstępne, Komisja Muzyki Kościelnej, podział stanowisk i wymagane kwalifikacje, uzupełnienie wykształcenia organisty, objęcie stanowiska, obowiązki organisty, wynagrodzenie, ofiary otrzymywane od wiernych i inne świadczenia, formy zatrudnienia organistów, zatrudnienie na podstawie umowy o pracę, ubezpieczenia i emerytura, nagrody i odprawy, prawo do urlopu, rozwiązanie umowy o pracę, zatrudnienie na podstawie umowy-zlecenia, wolontariat, dane osobowe, przepisy końcowe. Zawiera także załącznik nr 1, w którym określono czas pracy organisty oraz jego wynagrodzenie. Regulamin zawiera także 12 rodzajów umów i skład aktualnej Komisji Muzyki Kościelnej oraz dane teleadresowe Archidiecezjalnej Szkoły Muzycznej I i II stopnia im. Ks. Kardynała Franciszka Macharskiego oraz Międzyuczelnianego Instytutu Muzyki Kościelnej. Obie te instytucje kształcące organistów mają swoją siedzibę w Centrum Muzyki Kościelnej archidiecezji krakowskiej, które mieści się w Krakowie na ul. Prostej 35A.

Wiele zagadnień z regulaminu poruszano już we wcześniejszych jego wersjach. W omawianym regulaminie nowościami są: określenie jasno czasu pracy organisty i konkretnej zapłaty (regulamin zawiera coś w rodzaju cennika), ponowne podkreślenie wymaganych kwalifikacji i możliwości ich podnoszenia (uzupełnienia), wprowadzenie wizytacji parafii archidiecezji od strony muzycznej (przed wizytacją biskupa), wprowadzenie certyfikatów wydawanych po wizytacjach dla tych, którzy mogą grać w kościele.

Największe emocje - jak nie trudno się dziwić - wzbudza załącznik nr 1 pt. Czas pracy i wynagrodzenie $e^{33}$ do Regulaminu organistów archidiecezji krakowskiej, bowiem pozostałe sprawy były już częściowo wcześniej omawiane. Oto więc koncepcja tegoż załącznika: ze względu na specyfikę zawodu organisty (różny czas trwania poszczególnych mszy św. i nabożeństw, praca w dni świąteczne, prowadzenie zespołów śpiewaczych, dodatkowe czynności zlecone przez parafię itp.) przyjmuje się następujące reguły ustalania i rozliczania czasu pracy, która świadczona jest na podstawie odpłatnej umowy (umowy o pracę, odpłatnej umowy-zlecenia):

Podstawowe wskaźniki rozliczania czasu pracy:

- msza święta = 1 godzina (jednostka),

- nabożeństwo = 0,5 godziny (pół jednostki),

- przerwy poniżej jednej godziny wliczane do czasu pracy,

\footnotetext{
32 Tamże, s. 4.

${ }_{33}$ Zob. Regulamin organistów archidiecezji krakowskiej, dz. cyt.
} 
- prowadzenie chóru lub scholi $=5$ godzin $(2 \times 1,5$ godziny próby +2 godziny przygotowania),

- ćwiczenie na instrumencie $=5$ godzin,

- inne czynności (dbanie o instrument, przygotowanie tekstów pieśni itp.) = 1 godzina,

- dodatkowe dni świąteczne (poza niedzielami) = liczba godzin jak w każdą niedzielę w skali miesiąca,

- ślub = 1 godzina,

- pogrzeb = 2 godziny.

Przykładowy sposób ustalenia wymiaru czasu pracy organisty zatrudnionego na podstawie umowy o pracę - w przypadku, gdy jego zadania nie odpowiadają pełnemu wymiarowi czasu pracy, tj. przeciętnie 40 godzinom tygodniowo w okresie rozliczeniowym: np. przeciętnie w tygodniu, w ciągu okresu rozliczeniowego (tj. w okresie 4 miesięcy), organista gra:

\begin{tabular}{ll} 
na 10 mszach św. & 10 godzin, \\
na 2 nabożeństwach & 1 godzina, \\
3 dni ćwiczy na instrumencie & 5 godzin, \\
\hline łącznie & 26 godzin.
\end{tabular}

Jeżeli tygodniowy schemat zadań organisty będzie powtarzalny w ciągu okresu rozliczeniowego, tj. w okresie 4 miesięcy, możemy przyjąć, że przeciętnie (przeciętnie - tj. w jednym tygodniu liczba godzin może być mniejsza, a w innym większa, co na koniec okresu rozliczeniowego pozwoli ustalić średnią liczbę godzin) organista pracuje w wymiarze 26/40 etatu. Pełny etat wynosi bowiem 40 godzin tygodniowo. Stąd etat (wymiar czasu pracy) ustalamy za pomocą ułamka $26 / 40=13 / 20$ etatu.

1. Śluby i pogrzeby w przypadku zatrudnienia na podstawie umowy o pracę mogą być rozliczane na dwa sposoby:

- Czas pracy organisty podczas tych uroczystości należy uwzględniać w wymiarze jego czasu pracy (etacie) i wówczas są opłacane w ramach zawartej z organistą umowy, według następujących reguł: ślub - 1 godzina, pogrzeb - 2 godziny.

- Parafia ustala, że śluby i pogrzeby nie są wliczane do czasu pracy, a wówczas honorarium z tytułu oprawy muzycznej tych uroczystości wypłacają organiście wierni na podstawie umowy cywilno-prawnej zawartej z organistą.

2. Jeśli w okresie rozliczeniowym (tj. po upływie 4 miesięcy) liczba (czas) czynności określonych w pkt. 1 niniejszego załącznika, do wykonania których zobowiązany jest organista zatrudniony na podstawie umowy o pracę, przewyższać 
będzie obowiązujący go wymiar etatu, wówczas organiście przysługiwać będzie stosowny dodatek do wynagrodzenia, w wysokości ustalonej zgodnie z przepisami kodeksu pracy.

3. W przypadku zatrudnienia organisty $\mathbf{w}$ pełnym wymiarze czasu pracy ustala się następujące minimalne stawki godzinowe za wypracowaną przez organistę jednostkę czasu pracy dla poszczególnych kategorii, o których mowa w $\$ 6 R e$ gulaminu organistów archidiecezji krakowskiej:

- kategoria I - 25 zł brutto,

- kategoria II - 20 zł brutto,

- kategoria III - 15 zł brutto.

4. W przypadku zatrudnienia organisty $\mathbf{w}$ niepełnym wymiarze czasu pracy stawki godzinowe, o których mowa w pkt. 4, przysługują organiście w wyższej wysokości, ustalonej przez rządcę parafii z organistą, przy uwzględnieniu następujących kryteriów i celów:

- wymiaru czasu pracy, w którym zatrudniony jest organista,

- możliwości finansowych parafii,

- zapewnienia organiście godziwego wynagrodzenia.

5. Minimalna wysokość stawek przysługujących organiście zatrudnionemu w niepełnym wymiarze czasu pracy nie powinna być niższa od stawek określonych w pkt. 4 powiększonych o $20 \%$. Rządca parafii z uwagi na jej trudną sytuację finansową może ustalić minimalną wysokość stawek w niższej wysokości, nie niższej jednak niż wysokość stawek, o których mowa w pkt 4.

\section{To, co napawa nadzieją}

Warto na koniec postawić pytanie: Czy wszystkie te zabiegi przyniosły oczekiwane efekty? Może odpowiedzią niech będą następujące fakty:

- Praca nad zmianą myślenia o ważności muzyki kościelnej w archidiecezji krakowskiej w ostatnim czasie to lata 1997-2012.

- Umowę o pracę zawarto w 150 parafiach (35\% w archidiecezji), umowę-zlecenie w 15 parafiach, wolontariat w 90 parafiach, inne (nie ma organisty, porozumienie stron, etc.) w 55 parafiach. Razem więc jest 310 parafii $(67 \%)$.

- Umowa o pracę jest też najczęstszą formą zatrudnienia po wprowadzonym nowym regulaminie. Niemniej jednak brakuje wciąż określenia formy zatrudnienia w pozostałych przeszło 150 parafiach i ośrodkach duszpasterskich archidiecezji. Część z nich jest zbyt mała, by zatrudniać organistę, części na to nie stać, ale są i takie, gdzie świadomość nieustannie wzrasta. 
- W Archidiecezjalnej Szkole Muzycznej II stopnia kształci się 80 słuchaczy, a w Międzyuczelnianym Instytucie Muzyki Kościelnej blisko 40 studentów.

- Najważniejsze kościoły obsadzili organiści ze stopniem magistra i są to ludzie kreatywni.

- Członkami Archidiecezjalnej Komisji Muzyki Kościelnej są ludzie uznani za autorytety w środowisku muzycznym archidiecezji (świeccy i duchowni).

- Biskup diecezjalny w Krakowie popiera nieustanny rozwój organistów i podnoszenie poziomu muzyki kościelnej (daje temu dowód, pisząc listy od 2005 roku we wspomnienie św. Cecylii; dotąd ukazało się 7 listów).

- Dniami skupienia i rekolekcjami obejmuje się około 200 organistów.

- Po wydaniu Regulaminu budowy, remontów i sprowadzania z zagranicy instrumentów wzrosła dbałość o organy.

- Od jesieni 2012 roku mają rozpocząć się w diecezji wizytacje parafii od strony muzycznej.

\section{Summary}

The proceedings towards the regulation of organists' status in church life in the Cracow Diocese have had a long and interesting history. The history which featured wise bishops, as well as brave seculars and clergy who have raised this issue. The presented facts perhaps help to understand complexity of the problem and demonstrate what has been accomplished for the last several years.

It was the years 1997-2012 that intensive works on changing the attitude towards the significance of sacred music were carried out in the Cracow Archdiocese; Employment contracts were signed in 150 parishes (35\% of Archdiocese), contracts for specific works - in 15 parishes; voluntary employment contracts in 90; and others (no regulations, mutual agreements, etc.): in 55 parishes. The total number amounts to $310(67 \%)$. Clearly, upon introducing new regulations an employment contract is the commonest form of employment. Nevertheless, as figures show, in over 150 parishes and other pastoral centers of the archdiocese employment has not been regulated so far. It is perhaps because some parishes are too small to employ an organist, some simply cannot afford the one, yet in many of them the awareness of this problem has systematically risen. The Archdiocesan School of Music of $2^{\text {nd }}$ Degree has 80 students, and the Intercollegiate Institute for Church Music - almost 40. The organists' posts at primary 
archdiocesan churches are held by musicians with master degrees who are the organists of great creativity. The members of the Archdiocesan Commission for Church Music are the authorities commonly recognised in the music milieu of the archdiocese (both seculars and clergy). Organists' self-development and improvement of sacred music towards higher standards have been given constant support from the Cracow diocesan bishop (as proved by his letter of 2005 written of the Feast of St. Cecilia; and by 7 other letters so far). Days of reflection and retreats are organised for about 200 organists. After issuing The Rules and Regulations of Instruments Renovation and Ordering from Abroad care for pipe organist has risen considerably. In autumn 2012 visiting parishes, with regard to music, is planned to be carried out. 